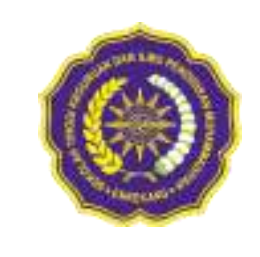

\title{
PENGEMBANGAN PERANGKAT PEMBELAJARAN MATEMATIKA BERBASIS MASALAH DENGAN PENDEKATAN SAINTIFIK PADA POKOK BAHASAN GEOMETRI UNTUK PESERTA DIDIK SMA KELAS $X$
}

\author{
Rustiani S; Hafsyah; Putriyani S \\ Program Studi Pendidikan Matematika, ST KIP Muhammadiyah Enrekang, Indonesia \\ Email Coresspondent: ${ }^{1}$ rustiani@ummaspul.ac.id., ${ }^{2}$ hafsyah@ummaspul.ac.id; Email: \\ 3.putriyanisamsul@ummaspul.ac.id
}

\begin{abstract}
This study was a research and development which aimed at developing and producing mathematics learning tool for Geometry learning which was valid, reliable, objective, and practical.The product expected from this study was the learning tools on the topic of Geometry which was valid $(R>85 \%)$, practical $(\bar{x}$ observe $=2)$, and effective (THB $=85,7 \%$, students activity $>80 \%$, and positive response 98,7\%). The product was consisted of 8 components, namely (1) Lesson plan; (2) Text book; (3) Worksheet; (4) Evaluation test of learning tools; (5) Observation sheet of students activity; (6) Observation sheet on implementation of learning tool; (7) questionnaire of students respons; and (8) validation sheet. The development process of authentic evaluation instrument used the modification of 4-D Model from Thiagarajan.The tried out was conducted at SMAN 1 Enrekang to grade $X$ students. The result of the study revealed that the development of authentic evaluation instrument for Geometry learning which was valid, reliable, objective, and practical. Suggestion for this study are (1) other researchers who are interested in developing this study should learn the limitation of this study and (2) the development of authentic evaluation instrument for Geometry learning should also develop other subject materials to assist teachers in evaluating student's based on their competence.
\end{abstract}

KeyWords:Development Learning Tool, Problem Based, Scientific Approach

\begin{abstract}
Abstrak-Penelitian ini adalah penelitian pengembangan (Research and Development).Tujuan penelitian ini adalah untuk mengembangkan dan menghasilkan perangkat dalam pembelajaran geometri yang valid, praktis, dan efektif.Produk yang dikehendaki dalam penelitian ini adalah perangkat pembelajaran geometri yang valid, praktis dan efektif. Produk tersebut terdiri dari 8 komponen, yaitu (1) RPP; (2) Buku teks pelajaran; (3) Lembar kerja; (4) Tes uji coba perangkat; (5) lembar observasi aktivitas peserta didik; (6) lembar observasi keterlaksanaan perangkat pembelajaran; (7) angket respon peserta didik; (8) lembar validasi. Proses pengembangan perangkat pembelajaran menggunakan modifikasi model 4-D dari Thiagarajan.Ujicoba dilakukan di SMA Negeri 1 Enrekang pada peserta didik kelas X IPA 2.Hasil yang diperoleh pada ujicoba tersebut adalah pengembangan perangkat pembelajaran geometri yang valid $(\mathrm{R} .85 \%)$, praktis $(\bar{x}$ pengamatan $=$ 2) dan efektif (ketuntasan hasil THB $=85,7 \%$, aktivitas peserta didik $>80 \%$, dan respon positif, 97,8\%). Sebagai implikasi yang diperoleh dari perangkat ini, disarankan: (1) kepada pendidik Matematika untuk dapat menggunakan perangkat ini pada materi Geometri, (2) untuk keperluan pengembangan selanjutnya, pendidik diharapkan dapat mengembangkan sendiri perangkat pembelajaran (RPP, buku teks pelajaran, lembar kerja dan tes hasil belajar) yang disesuaikan dengan pembelajaran berbasis masalah dengan pendekatan saintifik., (3) bagi peneliti yang berminat melakukan penelitian pengembangan perangkat agar mencermati segala kelemahan dan keterbatasan penelitian ini, sehingga penelitian yang dilakukan dapat menghasilkan perangkat yang lebih valid, praktis, dan efektif..
\end{abstract}

Kata Kunci: Pengembangan perangkat, , Berbasis Masalah, Pendekatan Saintifik

\#\# HowToCite\#\#

Aminullah (2018). Pengembangan Perangkat Pembelajaran Matematika Berbasis Masalah dengan Pendekatan Saintifik Pada Pokok Bahasan Geometri untuk Peserta Didik SMA Kelas X. Edumaspul - Jurnal Pendidikan, 2(2), 1-12 


\section{PENDAHULUAN}

\subsection{LatarBelakang}

Salah satu penyebab kesulitan yang bersumber dari luar peserta didik adalah rendahnya kemampuan pendidik dalam menggunakan metode pembelajaran yang bervariasi.Dibutuhkan profesionalisme dan kreativitas pendidik dalam kegiatan pembelajaran, salah satunya yaitu mampu menyusun perangkat pembelajaran yang sesuai dengan Kurikulum 2013.Strategi pembelajaran yang sesuai dengan Kurikulum 2013 adalah pendekatan sainitifik.

Pembelajaran akan bermakna apabila dalam proses pembelajaran pendidik mengaitkan materi yang dipelajari dengan permasalahan yang berkaitan dengan lingkungan sekitar (Putriyani, dan Muthamainnah, 2018). Dengan semangat belajar seraya berlomba mengacungkan tangan untuk mengungkapkan pendapat masingmasing.Peserta didik yang awalnya sering diam pun ikut memberi pendapat mengenai solusi masalah yang diberikan oleh pendidik.

Model pembelajaran yang tepat digunakan yaitu model pembelajaran berbasis masalah. Beberapa penelitian dengan beragam subyek melaporkan keunggulan model pembelajaran berbasis masalah (Sumarmo, Hidayat, Zulkarnen, Hamidah, dan Sariningsih, 2012; Redhana, 2013; Padmavathy, 2013, Mulyana dan Sumarmo, 2015; Supraptinah, Budiyono, dan Subanti, 2015).Model pembelajaran berbasis masalah menyajikan masalah kontekstual diawal pembelajaran kemudian masalah tersebut diselidiki oleh peserta didik dengan bantuan scaffolding oleh pendidik untuk mengetahui solusi dari masalah tersebut.Cara seperti ini merupakan stimulus yang dapat meningkatkan minat belajar dan kreativitas peserta didik terutama dalam hal pemecahan masalah sehingga perkembangan non-kognitif selaras dengan perkembangan kognitif yang dimiliki peserta didik.

Sementara pendekatan pembelajaran yang sangat cocok disandingkan dengan model pembelajaran berbasis masalah adalah pendekatan saintifik yang mengarahkan pendidik harus menyajikan pembelajaran yang dapat meningkatkan rasa keingintahuan, meningkatkan keterampilan mengamati, melakukan analisis dan berkomunikasi.

Oleh karena itu penelitian ini dilakukan untuk mengembangkan perangkat pembelajaran matematika.Atas dasar pemikiran tersebut, maka akan dilakukan penelitian dengan judul "Pengembangan Perangkat Pembelajaran Berbasis Masalah dengan Pendekatan Saintifik pada Pokok Bahasan Geometri Untuk Peserta Didik SMA Kelas X”.

\subsection{Pertanyaan Penelitian}

Berdasarkan latar belakang yang telah diuraikan di atas maka pertanyaan penelitian adalah bagaimana mengembangkan perangkat pembelajaran berbasis masalah dengan pendekatan saintifik pada pokok bahasan Geometri untuk peserta didik SMA Kelas X yang valid, praktis, dan efektif?

\subsection{Tujuan Penelitian}

Tujuan penelitian ini adalah untuk memperoleh perangkat pembelajaran berbasis masalah dengan pendekatan saintifik pada pokok bahasan Geometri untuk peserta didik SMA Kelas $\mathrm{X}$ yang valid, praktis, dan efektif. Perangkat pembelajaran tersebut adalah Silabus, Rencana Pelaksanaan Pembelajaran (RPP), Buku Teks Pelajaran, Lembar Kerja (LK) dan Penilaian Hasil Belajar (PHB). 


\section{METODE PENELITIAN}

Jenis penelitian ini adalah penelitian pengembangan yakni pengembangan perangkat pembelajaran yang terdiri atas: 1) Rencana Pelakasanaan Pembelajaran (RPP), 2) Buku Teks Pelajaran, 3) Lembar Kerja (LK), dan 4) Penilaian Hasil Belajar (PHB).

Penelitian ini akan dilaksanakan di SMA Negeri 1 Enrekang dengan subjek penelitian adalah peserta didik Kelas $\mathrm{X}$ pada semester ganjil tahun pelajaran 20182019.Model pengembangan perangkat yang digunakan dalam penelitian ini mengacu pada pengembangan four $D$ Models (model 4-D) yang terdiri atas empat tahap, yaitu pendefinisian (define), perancangan (design), pengembangan (develop), dan penyebaran (disseminate), sebagaimana dikemukakan oleh Thiagarajan, Semmel \& Semmel (1974). Instrumen dan teknik pengumpulan data diuraikan sebagai berikut:

a Lembar validasi perangkat pembelajaran. Lembar validasi digunakan untuk memperoleh data tentang hasil validasi para ahli mengenai Rencana Pelaksanaan Pembelajaran (RPP), buku teks pelajaran, Lembar Kerja (LK) dan penilaian hasil belajar

b Lembar Observasi.Instrumen yang digunalkan untuk mengetahui keefektifan dan kepraktisan perangkat pembelajaran digunakan dua macam lembar observasi yaitu: (1) lembar observasi keterlaksanaan perangkat pembelajaran, dan (2) lembar observasi aktivitas siswa. Observasi dilakukan setiap pertemuan dengan mengacu pada aspek-aspek pengamatan yang diberikan.

c Penilaian Hasil Belajar.Instrumen ini disusun dengan mengacu pada kompetensi dasar dan indikator selanjutnya diujicobakan kepada peserta didik. Data hasil ujicoba ini dijadikan sebagai bahan pertimbangan untuk memperbaiki perangkat yang telah disusun.
Data hasil validasi para ahli dan praktisi untuk masing-masing perangkat pembelajaran dianalisis dengan kategori hasil: sangat baik, baik, cukup baik, kurang baik, dan tidak baik sesuai dengan Tabel 2.1.

Tabel 1. Pendeskripsian Rerata Skor Validasi

\begin{tabular}{|c|c|}
\hline Skor Validasi & Kriteria \\
\hline $\begin{array}{c}1,00 \leq \text { rerata skor } \\
\text { validasi } \leq 1,50\end{array}$ & Tidak baik \\
\hline $\begin{array}{c}1,50 \leq \text { rerata skor } \\
\text { validasi } \leq 2,50\end{array}$ & Kurang baik \\
\hline $\begin{array}{c}2,50 \leq \text { rerata skor } \\
\text { validasi } \leq 3,50\end{array}$ & Cukup baik \\
\hline $\begin{array}{c}3,50 \leq \text { rerata skor } \\
\text { validasi } \leq 4,50\end{array}$ & Baik \\
\hline $\begin{array}{c}4,50 \leq \text { rerata skor } \\
\text { validasi } \leq 5,00\end{array}$ & Sangat Baik \\
\hline
\end{tabular}

(Machmud, Ismail, \& Bito, 2015)

Data hasil keterlaksanaan perangkat pembelajaran dianalisis berdasarkan rerata aspek pengamatan.Pendeskripsian kategori keterlaksanaan perangkat pembelajaran dijelaskan pada Tabel 2.

Tabel 2. Kategori Rerata Aspek Pengamatan Keterlaksanaan Perangkat Pembelajaran

\begin{tabular}{|c|l|}
\hline Rerata Aspek Pengamatan & Kriteria \\
\hline $0,00 \leq$ rerata skor validasi $\leq 0,50$ & $\begin{array}{l}\text { Tidak } \\
\text { terlaksana }\end{array}$ \\
\hline $0,50 \leq$ rerata skor validasi $\leq 1,50$ & $\begin{array}{l}\text { Terlaksana } \\
\text { sebagian }\end{array}$ \\
\hline $1,50 \leq$ rerata skor validasi $\leq 2,00$ & $\begin{array}{l}\text { Terlaksana } \\
\text { seluruhnya }\end{array}$ \\
\hline
\end{tabular}

(Nurdin, 2007)

Untuk pengkategorian kemampuan pendidik mengelola pembelajaran ditunjukkan pada Tabel 3.

Tabel 3. Kategori Rerata Aspek Pengamatan Kemampuan Pendidik Mengelola Pembelajaran

\begin{tabular}{|c|c|}
\hline $\begin{array}{c}\text { Rerata Aspek Pengamatan } \\
\text { (KG) }\end{array}$ & Kriteria \\
\hline $\mathrm{KG}<1,5$ & Sangat rendah \\
\hline $1,50 \leq \mathrm{KG} \leq 2,50$ & Rendah \\
\hline $2,50 \leq \mathrm{KG} \leq 3,50$ & Sedang \\
\hline $3,50 \leq \mathrm{KG} \leq 4,50$ & Tinggi \\
\hline $4,50<\mathrm{KG}$ & Sangat Tinggi \\
\hline
\end{tabular}

(Nurdin, 2007) 
Data dari hasil pengamatan aktivitas peserta didik selama kegiatan pembelajaran dianalisis berdasarkan persentase.

Tabel 4. Kriteria Batasan Waktu Ideal dan Batasan Keefektifan Aktivitas Peserta Didik

\begin{tabular}{lcc}
\hline \multicolumn{1}{c}{$\begin{array}{c}\text { Kategori } \\
\text { Pengamatan }\end{array}$} & $\begin{array}{c}\text { Waktu } \\
\text { Ideal }\end{array}$ & Toleransi \\
\hline $\begin{array}{l}\text { Mendengarkan/ } \\
\text { memperhatikan } \\
\text { penjelasan guru/ } \\
\text { teman }\end{array}$ & $19 \%$ & $\begin{array}{c}14 \% \leq \mathrm{P}< \\
24 \%\end{array}$ \\
\hline $\begin{array}{l}\text { Membaca masalah } \\
\text { dalam LK }\end{array}$ & $18 \%$ & $13 \% \leq \mathrm{P}<$ \\
\hline $\begin{array}{l}\text { Menyelesaikan } \\
\text { masalah/ } \\
\text { menemukan cara } \\
\text { dan jawaban } \\
\text { masalah }\end{array}$ & $25 \%$ & $20 \% \leq \mathrm{P}<$ \\
\hline $\begin{array}{l}\text { Berdisikusi/ } \\
\text { bertanya antar } \\
\text { peserta didik }\end{array}$ & $20 \%$ & $30 \%$ \\
\hline $\begin{array}{l}\text { Menulis yang } \\
\text { relevan dengan } \\
\text { KBM }\end{array}$ & $12 \%$ & $7 \% \leq \mathrm{P}<$ \\
\hline $\begin{array}{l}\text { Menarik } \\
\text { kesimpulan dari } \\
\text { prosedur/ konsep }\end{array}$ & $6 \%$ & $17 \% \leq \mathrm{P}<$ \\
\hline $\begin{array}{l}\text { Perilaku yang tidak } \\
\text { relevan selama } \\
\text { kegiatan belajar } \\
\text { mengajar }\end{array}$ & $0 \%$ & $11 \%$ \\
\hline
\end{tabular}

(Machmud, et al, 2015)

Perangkat dan proses pembelajaran dikatakan efektif jika sekurang-kurangnya $75 \%$ dari semua peserta didik menjawab sangat setuju dan setuju atau rata-rata akhir dari skor respon peserta didik minimal berada pada kategori setuju.

Tes yang digunakan menggunakan Penilaian Acuan Patokan (PHP) sehingga analisis difokuskan pada analisis validitas, reliabilitas, dan sensitivitas.
Tabel 5. Kriteria Validitas Butir $\left(r_{x y}\right)$

\begin{tabular}{|c|c|}
\hline Validitas Butir & Kriteria Validitas Butir \\
\hline $\mathrm{r}_{\mathrm{xy}} \leq 0,20$ & $\begin{array}{c}\text { Validitas butir tes sangat } \\
\text { rendah }\end{array}$ \\
\hline $0,20<\mathrm{r}_{\mathrm{xy}} \leq 0,40$ & Validitas butir tes rendah \\
\hline $0,40<\mathrm{r}_{\mathrm{xy}} \leq 0,60$ & Validitas butir tes cukup \\
\hline $0,60<\mathrm{r}_{\mathrm{xy}} \leq 0,80$ & Validitas butir tes tinggi \\
\hline $0,80<\mathrm{r}_{\mathrm{xy}} \leq 1,00$ & $\begin{array}{c}\text { Validitas butir tes sangat } \\
\text { tinggi }\end{array}$ \\
\hline
\end{tabular}

(Suherman dalam Machmud, et al, 2015)

Dalam penelitian ini butir tes yang digunakan dikatakan valid jika mempunyai validitas butir tes minimal cukup sedangkan butir-butir tes yang memiliki validitas butir tes rendah dan sangat rendah akan direvisi.

Tes yang digunakan dalam penilaian hasil belajar juga diperhatikan reliabilitasnya.Berikut ini merupakan interpretasi koefisien reliabilitas tes yang digunakan.

Tabel 6. Kriteria Validitas Butir $\left(r_{x y}\right)$

\begin{tabular}{|c|c|}
\hline Validitas Butir & Kriteria Validitas Butir \\
\hline$\alpha \leq 0,20$ & Reliabilitas tes sangat rendah \\
\hline $0,20<\alpha \leq 0,40$ & Reliabilitas tes rendah \\
\hline $0,40<\alpha \leq 0,60$ & Reliabilitas tes sedang \\
\hline $0,60<\alpha \leq 0,80$ & Reliabilitas tes tinggi \\
\hline $0,80<\alpha \leq 1,00$ & Reliabilitas tes sangat tinggi \\
\hline
\end{tabular}

(Suherman dalam Machmud, et al, 2015)

Perangkat pembelajaran yang dikembangkan dikatakan baik jika semua aspek berikut terpenuhi:

1) Keefektivan keterlaksanaan perangkat pembelajaran dan kemampuan pendidik mengelola pembelajaran.

2) Keefektivan aktivitas peserta didik dalam pembelajaran.

3) Respon peserta didik terhadap pembelajaran positif.

4) Penilaian hasil belajar memenuhi kriteria valid, reliabel, dan sensitif. 


\section{HASIL DAN PEMBAHASAN}

\subsection{Analisis Kepraktisan Perangkat Pembelajaran}

\subsubsection{Komponem Sintaks (RPP) Pembelajaran Berbasis Masalah Dengan Pendekatan Saintifik.}

Hasil pengamatan terhadap keterlaksanaan perangkat pembelajaran berbasis masalah dengan pendekatan saintifikdapat dilihat pada Tabel 7.

Tabel 7. Hasil Pengamatan Keterlakasanaan Perangkat Pembelajaran Komponen Sintaks

\begin{tabular}{|c|c|c|c|c|c|c|c|c|c|}
\hline \multirow{3}{*}{ Aspek Yang Dinilai } & \multicolumn{9}{|c|}{ Hasil Pengamatan Pertemuan ke- } \\
\hline & \multicolumn{3}{|c|}{1} & \multicolumn{3}{|c|}{2} & \multicolumn{3}{|c|}{3} \\
\hline & 1 & II & $x$ & $\mathrm{I}$ & II & $x$ & I & II & $x$ \\
\hline $\begin{array}{l}\text { Sintaks (RPP) } \\
\text { 1. Mengorientasi peserta didik } \\
\text { terhadap masalah }\end{array}$ & 2 & 2 & 2 & 2 & 2 & 2 & 2 & 2 & 2 \\
\hline $\begin{array}{l}\text { 2. Mengorganisasikan peserta didik } \\
\text { belajar }\end{array}$ & 2 & 2 & 2 & 2 & 2 & 2 & 2 & 2 & 2 \\
\hline $\begin{array}{l}\text { 3. Membimbing penyelidikan } \\
\text { individual / kelompok. }\end{array}$ & 2 & 2 & 2 & 2 & 2 & 2 & 2 & 2 & 2 \\
\hline $\begin{array}{l}\text { 4. Mengembangkan dan menyajikan } \\
\text { hasil karya }\end{array}$ & 2 & 2 & 2 & 2 & 2 & 2 & 2 & 2 & 2 \\
\hline $\begin{array}{l}\text { 5. Menganalisa dan mengevaluasi } \\
\text { proses pemecahan masalah }\end{array}$ & 2 & 2 & 2 & 2 & 2 & 2 & 2 & 2 & 2 \\
\hline Agreement & & 5 & & & 5 & & & 5 & \\
\hline Disagrement & & 0 & & & 0 & & & 0 & \\
\hline Rata-rata pengamatan & & 2.00 & & & 2.00 & & & 2.00 & \\
\hline Rata-rata total & & & & & 2.00 & & & & \\
\hline
\end{tabular}

Tabel 7 menunjukkan bahwa dua pengamat sepakat bahwa kompenen sintaks pembelajaran berbasis masalah dengan pendekatan saintifik terlaksana sepenuhnya yaitu dari rentang $(1,5 \leq V \leq 2,0)$.

3.1.2. Interaksi Sosial Yang Terjadi Dalam Pembelajaran Berbasis Masalah Dengan Pendekatan Saintifik. Hasil Pengamat Terhadap Keterlaksanaan Pembelajaran.

Tabel 8. Hasil Pengamat Keterlaksanaan Komponen Interaksi Sosial

\begin{tabular}{|c|c|c|c|c|c|c|c|c|c|}
\hline \multirow{3}{*}{ Aspek Yang Dinilai } & \multicolumn{9}{|c|}{ Hasil Pengamatan Pertemuan ke- } \\
\hline & \multicolumn{3}{|c|}{1} & \multicolumn{3}{|c|}{2} & \multicolumn{3}{|c|}{3} \\
\hline & 1 & II & $x$ & I & II & $x$ & $\mathrm{I}$ & II & $x$ \\
\hline $\begin{array}{l}\text { Interaksi sosial (Buku Teks Pelajaran dan } \\
\text { Lembar Kerja) } \\
\text { 1. Interaksi (komunikasi) multi arah antara pendidik } \\
\text { dengan peserta didik dan antara peserta didik } \\
\text { dengan peserta didik. }\end{array}$ & 1 & 1 & & 2 & 2 & & 1 & 2 & \\
\hline $\begin{array}{l}\text { 2. Keaktifan peserta didik dalam mencari dan } \\
\text { mengumpulkan data yang sesuai dengan materi } \\
\text { yang ada pada buku teks pelajaran dan lembar } \\
\text { kerja. }\end{array}$ & 2 & 2 & 2 & 2 & 2 & 2 & 2 & 2 & 2 \\
\hline
\end{tabular}




\begin{tabular}{|c|c|c|c|c|c|c|c|c|c|}
\hline \multirow{3}{*}{ Aspek Yang Dinilai } & \multicolumn{9}{|c|}{ Hasil Pengamatan Pertemuan ke- } \\
\hline & \multicolumn{3}{|c|}{1} & \multicolumn{3}{|c|}{2} & \multicolumn{3}{|c|}{3} \\
\hline & 1 & II & $x$ & I & II & $x$ & I & II & $x$ \\
\hline 3. Keaktifan peserta didik dalam kelompok & 1 & 1 & & 2 & 1 & & 2 & 2 & \\
\hline $\begin{array}{l}\text { 4. Pemberian kesempatan dan penghargaan kepada } \\
\text { peserta didik untuk terlibat aktif dalam } \\
\text { pembelajaran }\end{array}$ & 2 & 2 & 2 & 2 & 2 & 2 & 2 & 2 & 2 \\
\hline Agreement & & 4 & & & 4 & & & 4 & \\
\hline Disagrement & & 0 & & & 0 & & & 0 & \\
\hline Rata-rata pengamatan & & 1.50 & & & 1.90 & & & 1.90 & \\
\hline Rata-rata total & & & & & .77 & & & & \\
\hline
\end{tabular}

Tabel 8 menunjukkan bahwa dua pengamat sepakat bahwa kompenen intraksi terlaksana sepenuhnya yaitu dari rentang $(1,5 \leq V \leq 2,0)$.

\subsubsection{Prinsip Reaksi.}

Hasil pengamatan terhadap keterlaksanaan komponen prinsip reaksi selama uji coba dapat dilihat pada tabel 9 .

Tabel 9. Hasil Pengamat Keterlaksanaan Perangkat Pembelajaran Komponen Prinsip Reaksi

\begin{tabular}{|c|c|c|c|c|c|c|c|c|c|}
\hline \multirow{3}{*}{ Aspek Yang Dinilai } & \multicolumn{9}{|c|}{ Hasil Pengamatan Pertemuan ke- } \\
\hline & & 1 & & & 2 & & & 3 & \\
\hline & 1 & II & $x$ & I & II & $x$ & $\mathrm{I}$ & II & $x$ \\
\hline 5. Pendidik memberikan penguatan yang positif & 2 & 2 & & 2 & 2 & & 1 & 2 & \\
\hline $\begin{array}{l}\text { 6. Pendidik menggunakan alat bantu pembelajaran } \\
\text { utnuk meningkatkan pemahaman serta mengukur } \\
\text { kemampuan belajar peserta didik sesuai rencana } \\
\text { yang ada pada RPP yaitu LK dan Tes Hasil } \\
\text { Belajar }\end{array}$ & 2 & 2 & 2 & 2 & 2 & 2 & 2 & 2 & 2 \\
\hline Agreement & & 4 & & & 4 & & & 4 & \\
\hline Disagrement & & 0 & & & 0 & & & 0 & \\
\hline Rata-rata pengamatan & & 2 & & & 2 & & & 2 & \\
\hline Rata-rata total & & & & & 2 & & & & \\
\hline
\end{tabular}

Tabel 3.3 menunjukkan bahwa dua pengamat sepakat bahwa kompenen prinsip reaksi terlaksana sepenuhnya yaitu dari rentang $(1,5 \leq V \leq 2,0)$.

\subsubsection{Komponen Pendukung}

Komponen pendukung yang terjadi dalam pembelajaran berbasis masalah dengan pendekatan saintifik.Hasil pengamat terhadap keterlaksanaan pembelajaran. 
Tabel 10. Hasil Pengamat Keterlaksanaan Perangkat Pembelajaran Komponen Pendukung

\begin{tabular}{|c|c|c|c|c|c|c|c|c|c|}
\hline \multirow{3}{*}{ Aspek Yang Dinilai } & \multicolumn{9}{|c|}{ Hasil Pengamatan } \\
\hline & \multicolumn{3}{|c|}{1} & \multicolumn{3}{|c|}{2} & \multicolumn{3}{|c|}{3} \\
\hline & 1 & II & $x$ & I & II & $x$ & I & II & $x$ \\
\hline $\begin{array}{l}\text { Sistem pendukung } \\
\text { 1. Buku teks Pelajaran. }\end{array}$ & 2 & 2 & 2 & 2 & 2 & 2 & 2 & 2 & 2 \\
\hline $\begin{array}{l}\text { 2. Rencana Pelaksanaan } \\
\text { Pembelajaran (RPP). }\end{array}$ & 2 & 2 & 2 & 2 & 2 & 2 & 2 & 2 & 2 \\
\hline 3. Lembar Kerja (LK) & 2 & 2 & 2 & 2 & 2 & 2 & 2 & 2 & 2 \\
\hline 4. Alat bantu pembelajaran & 2 & 2 & 2 & 2 & 2 & 2 & 2 & 2 & 2 \\
\hline Agreement & & 4 & & & 4 & & & 4 & \\
\hline Disagrement & & 0 & & & 0 & & & 0 & \\
\hline Rata-rata & & 2.00 & & & 2.00 & & & 2.00 & \\
\hline Rata-rata Total & & & & & 2.00 & & & & \\
\hline
\end{tabular}

Tabel 10 menunjukkan bahwa dua pengamat sepakat bahwa komponen pendukung terlaksana sepenuhnya yaitu dari rentang $(1,5 \leq V \leq 2,0)$.

Berdasarkan analisis seluruh komponen keterlaksanaan pembelajaran berbasis masalah dengan pendekatan saintifik yaitu komponen sintaks, intraksi sosial, prinsip reaksi, pendukung dapat disimpulkan bahwa komponen pada kategori terlaksana sepenuhnya yaitu 1.95 pada rentang $(1,5 \leq V \leq 2,0)$.

\subsection{Uji Keefektifan Perangkat \\ Pembelajaran}

Perangkat pembelajaran dikatakan efektif apabila kriteria-kriteria yang dipergunakan untuk menentukan keefektifan terpenuhi, yaitu: (a) ketercapaian hasil belajar peserta didik secara klasikal yakni minimal $75 \%$ peserta didik mencapai skor minimal 75 yang ditetapkan dari kriteria ketuntasan minimal (KKM), (b) semua aspek aktivitas peserta didik berada pada batas toleransi pencapaian waktu ideal yang telah ditetapkan, (c) lebih dari 50\% peserta didik memberikan respons positif terhadap perangkat pembelajaran

\subsubsection{Deskripsi Hasil Aktivitas Peserta Didik}

Aktivitas peserta didik tercantum pada tabel 11 berikut:

Tabel 11. Rekapitulasi Aktivitas Peserta Didik

\begin{tabular}{|c|c|c|c|c|}
\hline \multirow[t]{2}{*}{ No } & \multirow[t]{2}{*}{ Aktivitas } & \multicolumn{3}{|c|}{$\begin{array}{c}\text { Persentase } \\
\text { Pertemuan Ke- }\end{array}$} \\
\hline & & $\mathbf{I}$ & II & III \\
\hline 1 & Kehadiran & 94 & 100 & 100 \\
\hline 2 & Kesiapan Belajar & 67 & 94 & 100 \\
\hline 3 & Keaktifan & 56 & 83 & 94 \\
\hline 4 & $\begin{array}{l}\text { Bekerja sama dengan } \\
\text { Kelompok }\end{array}$ & 56 & 78 & 94 \\
\hline 5 & $\begin{array}{l}\text { Kemampuan } \\
\text { Berkomunikasi }\end{array}$ & 56 & 72 & 78 \\
\hline \multicolumn{2}{|c|}{$\begin{array}{c}\text { Jumlah Persentase Rata-rata } \\
(\%)\end{array}$} & 66 & 85 & 93 \\
\hline
\end{tabular}

Berdasarkan Tabel 11 terlihat bahwa selama kegiatan pembelajaran berbasis masalah dengan pendekatan saintifik peserta didik terlibat secara aktif. 


\subsubsection{Deskripsi Hasil Respon Peserta Didik}

Berdasarkan jawaban peserta didik yang tertuang dalam Angket Respon peserta didik diperoleh hasil sebagai berikut

\section{Tabel 12. Rekapitulasi Respon Peserta} Didik

\begin{tabular}{|c|c|c|}
\hline \multirow{3}{*}{ Aspek penilaian } & \multicolumn{2}{|c|}{ Respon } \\
\hline & + & - \\
\hline & $\%$ & $\%$ \\
\hline $\begin{array}{l}\text { 1. Apakah kamu merasa senang atau } \\
\text { tidak terhadap komponen } \\
\text { pembelajaran }\end{array}$ & $\begin{array}{c}98.5 \\
8\end{array}$ & 1.42 \\
\hline $\begin{array}{l}\text { 2. Apakah komponen pembelajaran } \\
\text { berikut ini bagimu baru atau tidak } \\
\text { ? }\end{array}$ & 88 & 12 \\
\hline $\begin{array}{l}\text { 3. Apakah kamu dapat memahami } \\
\text { dengan jelas atau tidak bahasa } \\
\text { yang digunakan }\end{array}$ & 100 & 0 \\
\hline $\begin{array}{l}\text { 4. Apakah kamu tertarik atau tidak } \\
\text { dengan penampilan } \\
\text { (tulisan/ilustrasi/gambar/letak } \\
\text { gambar) yang terdapat }\end{array}$ & 96 & 4 \\
\hline $\begin{array}{l}\text { 5. Apakah kamu berminat atau tidak } \\
\text { untuk mengikuti pembelajaran } \\
\text { selanjutnya, seperti yang baru saja } \\
\text { kamu ikuti? }\end{array}$ & 100 & 0 \\
\hline $\begin{array}{l}\text { 6. Apakah ada kemajuan yang kamu } \\
\text { rasakan setelah pembelajaran ini? } \\
\text { (seperti mudah memahami, } \\
\text { bersemangat dalam belajar, lebih } \\
\text { bertanggung jawab pada tugas, } \\
\text { mampu mengkomunikasikan ide } \\
\text { dan bekerjasama, dll) }\end{array}$ & 100 & 0 \\
\hline $\begin{array}{l}\text { 7. Bagaimana pendapatmu tentang } \\
\text { kegiatan belajar mengajar dengan } \\
\text { menggunakan perangkat } \\
\text { pembelajaran matematika yang } \\
\text { telah kamu gunakan selama } \\
\text { proses pembelajaran }\end{array}$ & 100 & 0 \\
\hline $\begin{array}{l}\text { 8. Apakah kamu setuju jika dalam } \\
\text { proses pembelajaran pendidik }\end{array}$ & & \\
\hline $\begin{array}{l}\text { menggunakan perangkat } \\
\text { pembelajaran matematika seperti } \\
\text { yang kalian gunakan selama } \\
\text { proses pembelajaran? }\end{array}$ & 100 & 0 \\
\hline Rata-Rata & 97.8 & 2.2 \\
\hline
\end{tabular}

Dari keseluruhan aspek yang diamati respon positif yang rata-rata diberikan pada peserta didik adalah $97.8 \%$ dan respon negatif $2.2 \%$. Dengan demikian menurut kriteria pada peserta didik yang merespon positif perangkat pembelajaran yang telah dikembangkan sehingga tidak ada perbaikan /revisi terhadap perangkat pembelajaran yang didasrkan pada respon peserta didik

\subsection{Deskripsi Hasil Penilaian Pembelajaran}

Hasil analisis deskrisip skor panilaian pembelajaran metematika peserta didik setelah pembelajaran dengan menggunakan pembelajaran berbasis masalah dengan pendekatan saintifik dilihat pada tabel 3.7 berikut:

Tabel 13. Statistik Skor Tes Hasil Belajar Kelas XIPA 2 SMAN 1 Enrekang

\begin{tabular}{cc}
\hline Variabel & Nilai Statistik \\
\hline Subjek penelitian & 28 \\
Rata-rata & 85 \\
Standar Deviasi & 12 \\
Rentang Skor & 50 \\
Skor Maksimun & 100 \\
Skor Minimum & 50
\end{tabular}

Apabila tes hasil belajar matematika peserta didik dianalisis maka persentase ketuntasan tes hasil belajar setelah diterapkan perangkat pembelajaran berbasis masalah dengan pendekatan saintifik dapat dilihat pada tebel 3.8 berikut:

Tabel 14. Deskripsi Tes Hasil Belajar Matematika

\begin{tabular}{cccc}
\hline Nilai & Frekuensi & Kategori & Persentase \\
\hline $\mathbf{0 - 7 4}$ & 4 & Tidak & $14,3 \%$ \\
$\mathbf{7 5 -}$ & 24 & Tuntas & $85,7 \%$ \\
$\mathbf{1 0 0}$ & & Tuntas & \\
\hline
\end{tabular}

Dari ketiga kriteria keefektifan, pada uji coba ketiga aspek yang terpenuhi yaitu: aktivitas peserta didik, respon peserta didik, tes hasil penilaian matematika. Berdasarkan kriteria dapat disimpulkan bahwa pada uji coba, perangkat pembelajaran sudah efektif karena telah memenuhi semua indikator keefektifan termasuk ketuntasan hasil belajar peserta didik. 
Hasil-hasil yang diperoleh diatas mengindikasikan bahwa pada uji coba yang dilakukan, perangkat pembelajaran telah memenuhi kriteria kevalidan, kepraktisan, dan keefektifan.

\subsection{Pembahasan Hasil Penelitian}

\subsubsection{Keterecapaian Tujuan Penelitian}

1. Kevalidan Perangkat

\section{Pembelajaran}

Dari hasil analisi kevalidan perangkat pembelajaran yang meliputi: (1) Rencana pelaksanaan Pembelajaran (RPP), (2) Buku teks pelajaran, (3) Lembar kerja (LK), (4) Tes hasil belajar. Nilai validasi berada dalam batas interval $(3,5 \leq V \leq 4)$, yang artinya keseluruhan perangkat berada pada kategori sangat valid dengan rebiabilitas $\mathrm{R} \geq 85 \%$ artinya berada pada kategori reliabel.

Berdasarkan dari hasil penelitian tersebut dapat disimpulkan bahwa keseluruhan perangkat pembelajaran tersebut telah memenuhi kriteria kevalidan dan kriteria reliabilitas.

\section{Kepraktisan}

Perangkat

\section{Pembelajaran}

Berdasarkan hasil pengamatan terhadap perangkat pembelajaran oleh pengamat menyatakan pembelajaran terlaksana dengan baik pada uji coba. Berdasarkan hasil penilaian pengamat, maka perangkat telah memenuhi kriteria kepraktisan.

\section{Keefektifan \\ Pembelajaran}

Perangkat

Berdasarkan kriteria keefektifan pembelajaran yang meliputi: (1) ketuntasan tes hasil belajar, dari 28 peserta didik terdapat $85,7 \%$ peserta didik yang telah tuntas belajar. Dengan demikian, penguasaan tes hasil belajar peserta didik sudah memenuhi standar ketuntasan klasikal. (2) aktivitas peserta didik; secara umum hasil analisis data aktivitas peserta didik menunjukkan bahwa aktivitas ke-1, ke-2 dan ke-3 pada setiap pertemuan berada pada rentang batas teleransi, dengan demikian dapat dikatakan bahwa aktivitas peserta didik sudah tercapai sesuai harapan berdasarka kriteria pada bab III. (3) Respon peserta didik; dari keseluruhan aspek yang diamati rata-rata respon positif yang diberikan oleh peserta didik adalah 98\% dan rata-rata respon negatif $2 \%$

Untuk mengkatagorikan keefektifan dari suatu perangkat pembelajaran, maka ketiga indikator kriteria tersebut harus terpenuhi, tetapi indikator pertama harus terpenuhi yaitu ketuntasan peserta didik. Dari ketiga komponen di atas, pada saat uji coba ketiga komponen terpenuhi, sehingga dapat disimpulkan bahwa perangkat pembelajaran berbasis masalah dengan pendekatan saintifik memenuhi kriteria keefektifan.

\subsubsection{Temuan Khusus}

Temuan khusus yang dianggap berkonstruksi dalam penelitian ini antara lain: (1) pada saat uji coba pertemuan pertama, pembagian kelompok memakai waktu lama karena setiap peserta didik berkeinginan duduk bersama dengan teman akrabnya sedangkan pembagian kelompok yang dilaksanakan bercampur dengan kemampuan berbeda sehingga tidak sesuai dengan waktu yang diperkirakan. Namun setelah mereka mengikuti proses pembelajaran dan mendapatkan skor perkembangan timnya barulah peserta didik menyadari akan manfaat model pembelajaran ini. Bahkan setelah berakhirnya penelitian ini peserta didik justru meminta model pembelajaran berbasis masalah untuk diteruskan pada proses pembelajaran selanjutnya. (2) aktivitas menyajukan pertanyaan kepada teman maupun pendidik pada pertemuan pertama melebihi dari waktu yang ditentukan, hal ini di sebabkan peserta didik tidak terbiasa dengan 
melakukan kativitas sendiri atau mengkontruksi pengetahuan sendiri dengan cara membuat pertayaan/masalah dan menyelesaiakan/memecahkan sendiri, sehingga mereka selalau bertanya dalam melakukan aktivitas dan kurang percaya diri selalu takut salah apa yang diperbuatnya.(3) pada proses pembelajaran peserta didik membuat permasalahan atau soal sangat sederhana ketika pendidik mengajukan suatu permasalahan/soal tingkat tinggi, peserta didik mengalami kesulitan dikarenakan kurangnya dasar operasi aljabar. Pada pertemuan selanjutnya peserta didik mulai antusian, aktif dalam kelompoknya memecahkan masalah yang ada pada Buku teks pelajaran dan lembar kerja (LK).Berdasarkan temuan-temuan di ini, maka diperoleh informasi bahwa pembelajaran dengan menggunakan perangkat pembelajaran berbasis masalah dengan pendekatan saintifik mempengaruhi antusias, minat dan lebih menarik perhatian peserta didik.

\subsubsection{Kendala-Kendala Selama Penelitian}

Ada beberapa kendala yang dialami selama kegiatan pengembangan, terutama dalam kegiatan ujicoba. Kendala-kendala yang dimaksud adalah sebagai berikut.

1. Pengamat (observer) merasa kesulitan melakukan kegiatan pengamatan dalam waktu yang bersamaan, walaupun sebelum ujicoba dilaksanakan pengamat sudah dilatih melakukan pengamatan.

2. Pengelolaan waktu yang telah dialokasikan di RPP, masih terasa sulit dicapai secara maksimal, terutama pada bagian materi yang mempunyai tingkat kesukaran yang tinggi. Misalnya pada sub pokok bahasan menentukan besar sudut.

3. Pada awal uji coba, peserta didik masih terkendala mengubah sikap kebiasaan sebelumnya yaitu mencatat apa yang diberika oleh pendidik, sehingga menerapkan suatu model pembelajaran dan pendekatan, peserta didik belum terbiasa menkontruksi pengetahuannya sendiri. Namun hal ini dapat diatasi dalam pembagian kelompok yang diatur dengan tingkat kemampuan peserta didik sehingga peserta didik yang berkemampuan tinggi membimbing yang berkemampuan sedang dan rendah, atau pendidik memberi arah/petunjuk di papan tulis. Untuk itu peserta didik perlu diberi masalah untuk diselesaikan sendiri dan tidak mudah menyerah dalam menyelesaiakannya.

\section{KESIMPULAN}

Berdasarkan hasil analisis dan pembahasan penelitian yang telah dikemukakan, serta dihubungkan dengan pertanyaan penelitian, maka dapat disimpulkan beberapa hal pokok yang berkaitan dengan pengembangan perangkat pembelajaran berbasis masalah dengan pendekatan saintifik sebagai berikut.

1. Proses pengembangan perangkat menggunakan model pengembangan perangkat Thiagarajan yang terdiri dari 4 tahap yaitu (1) pendefinisian (define), (2) perancangan (design), (3) pengembangan (develop), dan (4) penyebaran (dessiminate). Adapun langkah-langkah kegiatan pengembangan yang dilakukan oleh peneliti adalah sebagai berikut:

a. Tahap pendefinisian (define): kegiatan analisis awal-akhir, analisis peserta didik,analisis 
materi, analisis tugas dan spesifikasi tujuan pembelajaran

b. Tahap perancangan (design): meliputikegiatan pemilihan media, pemilihan format, dan rancangan awal perangkat pembelajaran (draft 1)

c. Tahap pengembangan (develop); meliputi kegiatan validasi ahli, revisi I (draft II), uji coba (darft III) sehingga diperoleh hasil pengembangan.

2. Perangkat pembelajaran yang dihasilkan pada penelitian ini adala perangkat pembelajaran berbasis masalah dengan pendekatan saintifik pada materi geometri untuk siswa kelas X SMA Negeri 1Enrekang yang terdiri dari:

a. Rencana Pelaksanaan Pembelajaran (RPP): RPP yang dihasilkan pada penelitian ini adalah satu RPP untuk3 kali pertemuan berisi garis besar tentang hal-hal yang akan dilakukan oleh pendidik dan peserta didik selama proses pembelajaran berlangsung dengan pembelajaran berbasis masalah dengan pendekatan saintifik.

b. Buku teks pelajaran ; Buku teks pelajaran merupakan panduan bagi peserta didik dalam kegiatan proses pembelajaran yang memuat materi pelajaran, dan latihan membuat soal/masalah berdasarkan situasi yang diberikan.

c. Lembar kerja (LK); merupakan salah asatu alat bantu pembelajaran, yang terdapat dalam buku teks pelajaran untuk 3 kali pertemuan yang berisikan aktivitas peserta didik latihan menyelesaikan masalah berdasarkan situasi yang diberikan. d. Tes hasil belajar; merupakan butir tes digunakan untuk mengetahui hasil pencapaian kompetensi peserta didik setelah mengikutu proses pembelajaran. tes hasil belajar mengacu pada kompetensi dasar yang ingin dicapai, dan dijabarkan kedalam indikator pencapaian kompetensi dan disusun dalam bentuk kisi-kisi tes hasil belajar, soal dalam bentuk uraian yang dilengkapi dengan pedoman penskoran.

3. Secara umum hasil pengembangan perangkat pembelajaran dalam penelitian ini valid, praktis, efektif. (a) Rencana Pelaksanaan Pembelajaran (RPP), Buku teks pelajaran, Lembar kerja (LK), dan Tes hasil belajar. Dikategorikan sangan valid. (b) praktis, berdasarkan hasil pengamatan oleh pengamat bahwa perangkat pembelajaran terlaksana dengan baik pada saat uji coba, dan (c) efektif, telah memenuhi tiga kategori kriteria yaitu ketuntasan tes hasil belajar secara klasikal tercapai, aktivitas peserta didik efektif dan respon terhadap pembelajaran positif.

\section{SARAN-SARAN}

Berdasarkan hasil dan temuan yang diperoleh dalam penelitian ini, dikemukakan beberapa saran sebagai berikut.

a. Penelitian ini sudah menghasilkan perangkat pembelajaran yang valid, praktis, dan efektif. Oleh karena itu, disarankan kepada pendidik matematika untuk dapat menggunakan perangkat ini pada materi geometri.

b. Untuk keperluan pengembangan selanjutnya, pendidik diharapkan dapat mengembangkan sendiri perangkat pembelajaran (RPP, Buku teks pelajaran, lembar kerja (LK), dan Tes hasil belajar) yang disesuaikan dengan pembelajaran 
berbasis masalah dengan pendekatan saintifik. Sehingga peserta didik akan lebih termotivasi dan dapat mengkontruksi sendiri ide/pengetahuannya sesuai dengan kerikulum 2013.

c. Bagi peneliti yang berminat melakukan penelitian pengembangan perangkat agar mencermati segala kelemahan dan keterbatasan penelitian ini, sehingga penelitian yang dilakukan dapat menghasilkan perangkat yang lebih valid, praktis, dan efektif.

\section{Daftar Pustaka}

Machmud, T., Ismail, S., \&Bito., N. (2015). Pengembangan Pembelajaran Berbasis Model Penemuan Terbimbing untuk Materi Bangun Ruang di SMP seProvinsi Gorontalo. Jurnal Paradikma, 8(3), 1-12.

Mulyana, A.,\& Sumarmo, U. (2015). Meningkatkan Kemampuan Penalaran Matematika dan Kemandirian Belajar Siswa SMP Melalui Pembelajaran Berbasis Masalah.Jurnal Didaktik, 9(1), 40-51.

Nurdin. (2007). Model Pembelajaran Matematika yang Menumbuhkan Kemampuan Metakognitif untuk Menguasai Bahan Ajar.Disertasi tidak diterbitkan. Surabaya: UNESA. 